\title{
A bone marrow niche-derived molecular switch between osteogenesis and hematopoiesis
}

\author{
Marta Galán-Díez and Stavroula Kousteni \\ Department of Physiology and Cellular Biophysics, College of Physicians and Surgeons, Columbia University, New York, \\ New York 10032, USA
}

\begin{abstract}
Hematopoietic stem cells (HSCs) reside and are maintained in specialized microenvironments within the bone marrow known as niches, which are comprised of various cell types. Among them, leptin receptor (LepR)-expressing CXC chemokine ligand 12 (CXCL12)-abundant reticular (CAR) cells are known to create a niche for HSCs and at the same time to give rise to osteoblasts. These two functions of CAR/LepR ${ }^{+}$cells appear to be tightly but inversely regulated to ensure adequate physical space for HSCs. However, how osteogenesis is prevented in CAR cells to maintain spaces available for HSCs and hematopoiesis remains unclear. In this issue of Genes \& Development, Seike and colleagues (pp. 359-372) report that the transcription factor early B-cell factor $(E b f 3)$ is preferentially expressed by CAR/LepR ${ }^{+}$cells and inhibits CAR cell differentiation into osteoblasts while at the same time maintaining self-renewal of $\mathrm{CAR} / \mathrm{LepR}^{+}$cells. Using conditional knockout and retroviral systems, the investigators show that loss of $E b f 3$ in CAR cells impairs HSC numbers and leads to osteosclerosis. This study provides novel insights into transcriptional requirements for CAR cell bone formation by identifying $\mathrm{Ebf} 3$ as a niche factor secreted from CAR/Lepr ${ }^{+}$cells that regulates the interplay between osteogenesis and hematopoiesis.
\end{abstract}

One of the critical and unique functions of the skeleton is to provide the anatomical spaces for maintaining hematopoiesis. Bone marrow is the main site of residence for hematopoietic stem cells (HSCs), where they self-renew, proliferate, or become progressively restricted to several committed precursors and/or single lineages that give rise to the different types of mature blood cells. In the bone marrow, HSCs interact dynamically with an intricate network of stromal cells. Such groups of cells comprise a collection of several specialized "microniches" that sustain hematopoiesis by influencing different func-

[Keywords: Ebf3; stem cell niche; hematopoietic stem cell; mesenchymal stem cell; bone]

Corresponding author: sk2836@cumc.columbia.edu

Article is online at http://www.genesdev.org/cgi/doi/10.1101/gad.314013. 118 . tions of HSCs such as homing, mobilization, quiescence, self-renewal, or lineage commitment. Instructive cues are provided as essential autocrine, endocrine, and paracrine signals as well as direct cell-cell interactions between the stromal niches and the HSCs.

Numerous studies have examined the role of the osteoblast lineage in HSCs and point toward the notion that osteoblast regulation of hematopoiesis depends on the stage of osteoblast differentiation (Sacchetti et al. 2007; Wu et al. 2008; Méndez-Ferrer et al. 2010; Calvi et al. 2012; Kunisaki et al. 2013). Whereas the most immature uncommitted progenitor subset influences HSC maintenance and proliferation, committed progenitors or mature osteoblasts tailor HSC differentiation along the lymphoid, myeloid, and erythroid lineages (Calvi et al. 2003; Zhu et al. 2007; Ding and Morrison 2013; Krevvata et al. 2014). Indeed, self-renewing osteoprogenitor cells in the marrow can form supportive HSC niches (Sacchetti et al. 2007). Mesenchymal stem cells (MSCs) of the endosteal niche in closest proximity to HSCs express secreted or cell surface molecules that regulate HSC quiescence (Nilsson et al. 2005; Silberstein et al. 2016). Nestin-positive MSCs produce soluble factors involved in HSC maintenance, such as CXC chemokine ligand 12 (CXCL12) and stem cell factor (SCF), and colocalize with HSCs, and their depletion results in HSC mobilization (Méndez-Ferrer et al. 2010). These observations suggested that osteogenesis and HSC maintenance in the marrow may be inversely related.

Perivascular niches regulate HSC maintenance and quiescence. An arteriolar niche marked by rare NG2 (CSPG4 ${ }^{+}$) pericytes inhibits HSC cycling and reduces functional long-term repopulating HSCs in the bone marrow (Kunisaki et al. 2013). A distinct perisinusoid niche containing the majority of dividing and nondividing HSCs appears to regulate the interplay between osteogenesis and hematopoiesis. Cells within the perisinusoid niche that express

(C) 2018 Galán-Díez and Kousteni This article is distributed exclusively by Cold Spring Harbor Laboratory Press for the first six months after the full-issue publication date (see http://genesdev.cshlp.org/site/misc/ terms.xhtml). After six months, it is available under a Creative Commons License (Attribution-NonCommercial 4.0 International), as described at http://creativecommons.org/licenses/by-nc/4.0/. 
high levels of CXCL12 and SCF (CXCL12-abundant reticular [CAR] cells) make up the majority of perivascular cells (Omatsu et al. 2010) and overlap with perisinusoidal cells, identified on the basis of their expression of the leptin receptor (LepR) (Zhou et al. 2014). CAR and CAR/LepR ${ }^{+}$ MSCs, representing $\sim 0.3 \%$ of bone marrow cells, include nearly all of the colony-forming unit fibroblasts /CFUFs), are the major source of adipocytes and osteoblasts in adult mouse bone marrow, and are required to support HSC maintenance. However, the majority of CAR/LepR ${ }^{+}$ cells might remain undifferentiated in the bone marrow cavity, and it remains unclear how osteogenesis is prevented in most CAR/LepR ${ }^{+}$cells to maintain the spaces available for HSCs and hematopoiesis.

To address this question, Seike et al. (2018) sought to identify transcriptional regulators of CAR cells and focused on transcription factors of the early B-cell factor (Ebf) family. They found that Ebf3 is preferentially expressed in CAR cells, as compared with endothelial, hematopoietic, and stromal cells of adult marrow. Lineage tracing of Ebf3-expressing CAR/LepR ${ }^{+}$cells was performed using triple-mutant mice expressing CreERT2 knocked into the endogenous Ebf3 locus, the Cxcl12GFP transgene, and Cre-activated Rosa26 tandem dimer Tomato (tdTomato). The number of Ebf3-expressing CAR cells, which give rise to adipocytes and osteoblasts in the bone marrow, remained stable over the course of $13 \mathrm{mo}$, suggesting that they have the capacity to self-renew. Conditional deletion of Ebf3 in CAR/LepR ${ }^{+}$cells or in all MSCs of developing limbs resulted in decreased numbers of long-term repopulating HSCs (LT-HSCs), megakaryocyte/erythrocyte progenitors (MEPs) proerythroblasts, common lymphoid progenitors (CLPs), and granulocyte/macrophage progenitors (GMPs). Moreover, in aged mice, the number of functional HSCs decreased. This compromised hematopoietic phenotype correlated with increased osteoblast numbers and osteogenesis and lower expression of Cxcl12 and Scf in CAR/LepR ${ }^{+}$cells. As a result, aged mice became osteosclerotic. Interestingly, residual platelet-derived growth factor receptor $\beta$-positive $\left(\mathrm{PDGFR} \beta^{+}\right) \mathrm{Sca}-1^{-} \mathrm{CD} 31^{-} \mathrm{CD} 45^{-}$and Ter119 ${ }^{-} \mathrm{CAR}$ cells had much higher expression levels of osteoblast markers. Collectively, these results showed that the hematopoietic stem and progenitor cell (HSPC) niche function of CAR cells was severely impaired and that the majority of CAR cells was more differentiated into the osteoblast lineage in the absence of $E b f 3$.

In order to deprive CAR cells of all of the Ebf isoforms expressed, the investigators inactivated both Ebf3 and Ebf1 in MSCs, including CAR cells. At 1 wk of age, bone marrow cavities were formed, and CAR cells showed unaltered numbers and normal morphology with long processes; however, they had increased expression of the osteoblast markers Osterix, Col1a1, and Osteocalcin and decreased expression of Cxcl12 and Scf compared with control animals. This suggested that the majority of CAR cells was more differentiated into the osteoblast lineage in mutant animals. Total hematopoietic cell counts and numbers of LT-HSCs, MEPs, proerythroblasts, CLPs, and GMPs were indeed reduced in mutants. By $26 \mathrm{wk}$ of age, double-knockout mice showed an occlusion of the marrow cavity and reduced CAR cell number. Therefore, $E b f 1 / E b f 3$ do not appear to define CAR cell fate during embryogenesis but are required to inhibit differentiation of CAR cells into the osteoblast lineage to maintain the marrow spaces.

To investigate the respective contributions of Ebf3 and Ebf1 in HSC maintenance and osteoblast differentiation, the investigators studied the skeletal and hematopoietic phenotypes of adult CAR/LepR ${ }^{+}$cell-specific $E b f 1^{-/}$; $\mathrm{Ebf3}^{+/-}$and $E b f 1^{-/} ; \mathrm{Ebf3}^{-/-}$mice. A severe reduction of HSC progenitors in the marrow resulted in extramedullary hematopoiesis and a marked increase in trabecular bone mass. This was due to increased osteoblast numbers without changes in osteoclasts, which was observed in $\mathrm{Ebf1}^{-/+}$; $\mathrm{Ebf3}^{-/-}$mice but not in $E b f 1^{-/-} ; \mathrm{Ebf3}^{+/-}$mice at $34 \mathrm{wk}$ of age. CAR cells from CAR/LepR ${ }^{+}$cell-specific $E b f 1^{-/+}$; $E b f 3^{-/-}$mice, but not $E b f 1^{-/-} ; E b f 3^{+/-}$mice, had higher expression of osteoblast markers. Therefore, the activity of one functional $E b f 3$ allele is sufficient to maintain marrow spaces and HSCs and suppress osteoblastogenesis, whereas one Ebf1 allele is not. Finally, overexpression of Ebf1 and $E b f 3$ in sorted CAR cells increased expression of Cxcl12 and Scf and decreased their osteogenic potential in culture. This effect was dependent on the DNA-binding domain of $E b f 3$.

In conclusion, this study identifies Ebf3 as the molecular trigger that acts in both a cell-autonomous and a cellnonautonomous manner in $\mathrm{CAR} / \mathrm{LepR}^{+}$cells-to suppress their differentiation to the osteoblast lineage so as to maintain their HSC-supporting function (Fig. 1). The precise characteristics of the osteolineage cells responsible for HSC support are of great interest, since they could be used to predict whether therapeutic strategies that regulate osteoblastic commitment could also be exploited to enhance the formation of HSC niches from nonniche cells.

\section{References}

Calvi LM, Adams GB, Weibrecht KW, Weber JM, Olson DP, Knight MC, Martin RP, Schipani E, Divieti P, Bringhurst FR, et al. 2003. Osteoblastic cells regulate the haematopoietic stem cell niche. Nature 425: 841-846.

Calvi LM, Bromberg O, Rhee Y, Weber JM, Smith JN, Basil MJ, Frisch BJ, Bellido T. 2012. Osteoblastic expansion induced by parathyroid hormone receptor signaling in murine osteocytes is not sufficient to increase hematopoietic stem cells. Blood 119: 2489-2499.

Ding L, Morrison SJ. 2013. Haematopoietic stem cells and early lymphoid progenitors occupy distinct bone marrow niches. Nature 495: 231-235.

Krevvata M, Silva BC, Manavalan JS, Galan-Diez M, Kode A, Matthews GB, Park D, Zhang CA, Galili N, Nikolas TL, et al. 2014. Inhibition of leukemia cell engraftment and disease progression in mice by osteoblasts. Blood 124: 2834-2846.

Kunisaki Y, Bruns I, Scheiermann C, Ahmed J, Pinho S, Zhang D, Mizoguchi T, Wei Q, Lucas D, Ito K, et al. 2013. Arteriolar niches maintain haematopoietic stem cell quiescence. Nature 502: 637-643. 

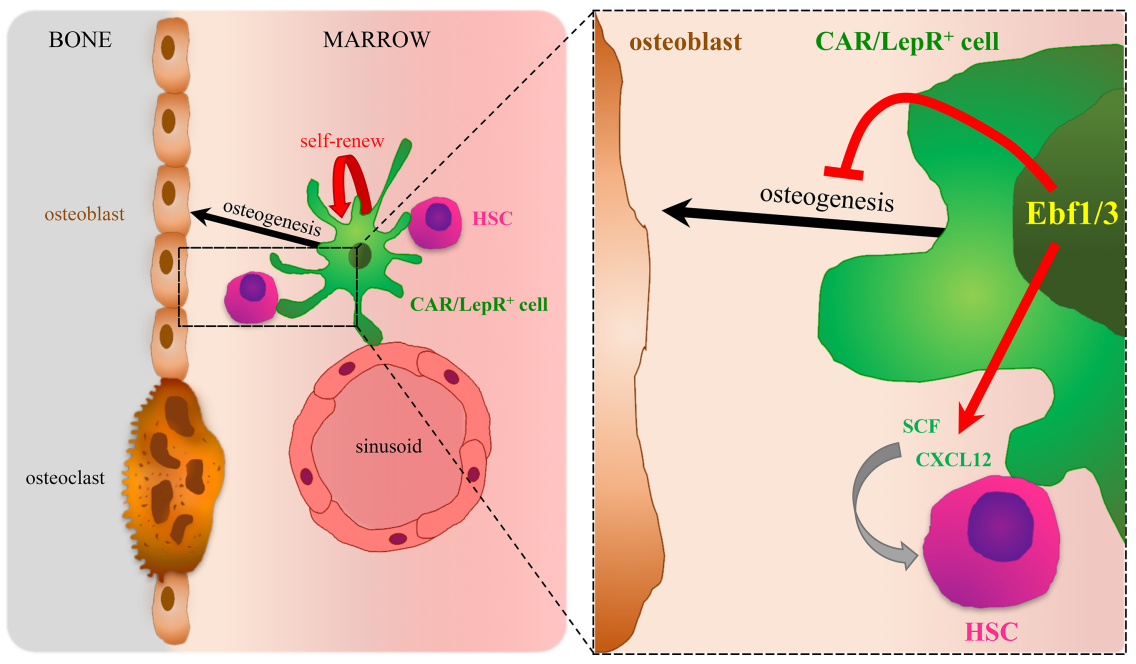

Figure 1. CAR/LepR ${ }^{+}$cells are MSCs surrounding sinusoids and/or near the endosteum. They express high levels of the chemokine Cxcl12, a key HSC niche factor that, together with Scf, regulates HSC maintenance and retention in the bone marrow niche. The osteogenic and adipogenic differentiation potentials of CAR/LepR ${ }^{+}$ cells are inhibited by the expression of the transcription factors $E b f 1 / 3$, ensuring that these specialized MSCs remain undifferentiated and allowing for marrow cavity maintenance by controlling Cxcl12 and Scf expression as well physically preserving the HSC niche.
Méndez-Ferrer S, Michurina TV, Ferraro F, Mazloom AR, Macarthur BD, Lira SA, Scadden DT, Ma'ayan A, Enikolopov GN, Frenette PS. 2010. Mesenchymal and haematopoietic stem cells form a unique bone marrow niche. Nature 466: 829-834.

Nilsson SK, Johnston HM, Whitty GA, Williams B, Webb RJ, Denhardt DT, Bertoncello I, Bendall LJ, Simmons PJ, Haylock DN. 2005. Osteopontin, a key component of the hematopoietic stem cell niche and regulator of primitive hematopoietic progenitor cells. Blood 106: 1232-1239.

Omatsu Y, Sugiyama T, Kohara H, Kondoh G, Fujii N, Kohno K, Nagasawa T. 2010. The essential functions of adipo-osteogenic progenitors as the hematopoietic stem and progenitor cell niche. Immunity 33: 387-399.

Sacchetti B, Funari A, Michienzi S, Di CS, Piersanti S, Saggio I, Tagliafico E, Ferrari S, Robey PG, Riminucci M, et al. 2007. Self-renewing osteoprogenitors in bone marrow sinusoids can organize a hematopoietic microenvironment. Cell 131: 324-336.
Seike M, Omatsu Y, Watanabe H, Kondoh G, Nagasawa T. 2018. Stem cell niche-specific Ebf3 maintains the bone marrow cavity. Genes Dev (this issue). doi: 10.1101/gad.311068.117.

Silberstein L, Goncalves KA, Kharchenko PV, Turcotte R, Kfoury Y, Mercier F, Baryawno N, Severe N, Bachand J, Spencer JA, et al. 2016. Proximity-based differential single-cell analysis of the niche to identify stem/progenitor cell regulators. Cell Stem Cell 19: 530-543.

Wu JY, Purton LE, Rodda SJ, Chen M, Weinstein LS, McMahon AP, Scadden DT, Kronenberg HM. 2008. Osteoblastic regulation of B lymphopoiesis is mediated by Gsa-dependent signaling pathways. Proc Nat1 Acad Sci 105: 16976-16981.

Zhou BO, Yue R, Murphy MM, Peyer JG, Morrison SJ. 2014. Leptin-receptor-expressing mesenchymal stromal cells represent the main source of bone formed by adult bone marrow. Cell Stem Cell 15: 154-168.

Zhu J, Garrett R, Jung Y, Zhang Y, Kim N, Wang J, Joe GJ, Hexner E, Choi Y, Taichman RS, et al. 2007. Osteoblasts support Blymphocyte commitment and differentiation from hematopoietic stem cells. Blood 109: 3706-3712. 


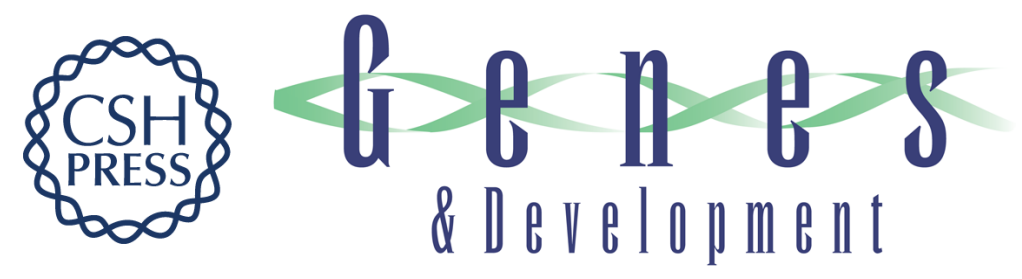

\section{A bone marrow niche-derived molecular switch between osteogenesis and hematopoiesis}

Marta Galán-Díez and Stavroula Kousteni

Genes Dev. 2018, 32:

Access the most recent version at doi:10.1101/gad.314013.118

\section{Related Content Stem cell niche-specific Ebf3 maintains the bone marrow cavity Masanari Seike, Yoshiki Omatsu, Hitomi Watanabe, et al. \\ Genes Dev. March , 2018 32: 359-372}

References This article cites 14 articles, 6 of which can be accessed free at: http://genesdev.cshlp.org/content/32/5-6/324.full.html\#ref-list-1

Articles cited in: http://genesdev.cshlp.org/content/32/5-6/324.full.html\#related-urls

Creative This article is distributed exclusively by Cold Spring Harbor Laboratory Press for the first Commons six months after the full-issue publication date (see License http://genesdev.cshlp.org/site/misc/terms.xhtml). After six months, it is available under a Creative Commons License (Attribution-NonCommercial 4.0 International), as described at http://creativecommons.org/licenses/by-nc/4.0/.

Email Alerting Receive free email alerts when new articles cite this article - sign up in the box at the top Service right corner of the article or click here.

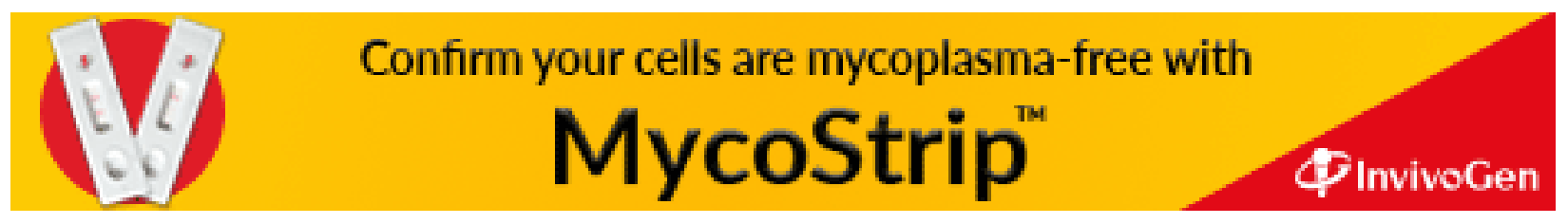

